\title{
Teaching of Basic Posture Skills in Visually Impaired Individuals and Its Implementation Under Aggravated Conditions
}

\author{
Ceren Suveren-Erdogan ${ }^{1} \&$ Sibel Suveren ${ }^{1}$ \\ ${ }^{1}$ Faculty of Sport Science, Gazi University, Turkey \\ Correspondence: Ceren Suveren-Erdogan, Faculty of Sport Science, Gazi University, Turkey.
}

Received: January 16, 2018

Accepted: February 10, 2018 Online Published: March 8, 2018

doi:10.5539/jel.v7n3p109

URL: https://doi.org/10.5539/jel.v7n3p109

\begin{abstract}
The aim of this study is to enable basic posture exercises to be included in the basic exercises of the visually impaired individuals as a step to learn more difficult movements, to guide the instructors in order to make efficient progress in a short time and to help more numbers of disabled individuals benefit from these studies.

Method: 15 visually impaired sedentary students from the Department of Special Education, the Gazi Faculty of Education, who take the course Physical Education and Game Teaching for Visually Impaired People participated in the study. Following the verbal information about the study, the visually impaired students were asked to try 5 movements with difficult conditions. During the next 10 weeks, he course continued in the practice section ( 1 day, 45 minutes per week) and all the basic postures, included in the program with the help of the instructor's verbal and physical help, were applied. 10 weeks later, visually impaired students were asked to retry the 5 movements which they were asked to do at the beginning of the program. The study was carried out with compilation method and the results were recorded on the basis of observation.

Conclusion: As a result of this study, it was observed that visually impaired individuals who have successfully learned the basic postures with verbal communication and physical help can apply movements with difficult conditions more easily and with fewer mistakes compared to the early attempts and movement qualities (technical production) have significantly increased. Based on this, it can be concluded that basic postures are of great benefit in movement training and progress of visually impaired individuals.
\end{abstract}

Keywords: basic posture skills, visually impaired, aggravated conditions

\section{Introduction}

Today, the importance of sports education for disabled people often comes to agenda. Progress in the area is very slow due to the inadequate resources and trainer's lack of knowledge.

The advancement of the technology and a passive life have been increasing the importance of exercise for health for all the individuals. Moreover, the disadvantages of a passive life may also affect the general health status of disabled people (Yılmaz, 2013; Suveren, 2003). When the practice of exercises are determined according to their needs, it facilitates the lives of disabled individuals (Gallahue, 1987).

Visual impairment is defined as "unrecoverable loss of vision that affects the educational attainment of a child in the negative direction" (Craft, 1995). Individuals who have lost sight and are incapable of eyesight experience problems of independent movement in social life due to the reasons such as lack of experience, lack of regular muscle activation, lack of motivation for movement and problems in perceiving the obstacles, and adversely affects the flows of movement and movement qualities (Coughlan et al., 2012; Horak, 1987; Deliceoğlu et al., 2017; Arslantekin, 2014; Montarzino et al., 2007; Havik, 2010). Disabled people need appropriate spatial and physical awareness to move adequately (Kalia et al., 2010; Altunay, 2003). Walking, posture, body control and body management are all independent parts of movement (Yılmaz, 2013; Pogrund et al., 1998)

Mobility independence consists of two aspects which are orientation and independent mobility. Independent functioning of people in the society depends on the possession of academic and daily life skills as well as attainment of orientation and independent mobility skills (Arslantekin, 2014).

Muscular weakness in visually impaired people can also cause posture problems. The absence of visual stimuli that affect the body movement, which is, hinderances in the visual-vestibular and proprioceptive mechanisms are 
among the causes of postural disorders (Coughlan et al., 2012; Horak, 1987; Deliceoğlu et al., 2017). Teaching independent mobility skills allows visually impaired individuals to develop more appropriate postures (Arslantekin, 2014).

In his study aiming to evaluate the development of gross motor skills of visually impaired children and to compare them with their sighted peers, Brambring (2006) assessed 29 gross motor skills of four congenitally blind children and concluded that four visually impaired children had developmental delays compared to the performances of their peers (Brambring, 2006).

In the exercise practices of individuals who do not see due to these and similar reasons, basic positions have a great importance in terms of warm-up and posture (bodybuilding) (Suveren, 2003).

The objective of this study is to establish a footing for the learning of more difficult movements by including the basic posture exercises in basic exercises of visually impaired individuals, and to give guidance to the educators for them to be able to make progress more efficiently in a shorter time and to enable more disabled people to benefit from these workouts.

\section{The Importance and Teaching Stages of Basic Position Education in Visually Impaired Individuals.}

\section{A. The Importance of Basic Posture Training in Visually Impaired Individuals}

Basic position exercises, head's position, coherent workouts of body and arms with the legs help to build the techniques of movements easier and more accurate through the pre-gains such as force and flexibility.

Appropriate activities selected for visually impaired people will improve the motor skills and thus take the balance status to the higher levels (Deliceoğlu et al., 2017; Murphy, 1989). For visually impaired individuals, exercise contents should be organized in a way to provide tactile, kinesthetic and auditory stimuli (Suveren, 2003; Pogrund et al., 1998).

The basic position and postures that will be taught to the visually impaired individuals can make it easier to use the leg, body, and arms in a new movement and prevent the loss of time in learning. A visually impaired individual can learn how to use his muscles, how to transfer weight, and how to stand on one's arms with tensed or twisted arms.

After learning the basic positions, complicating the conditions by fixing the movements will help to technical improvement as well as be an effective way of utilizing the time for the advancement of the learning of new movements (Suveren, 2002).

Individuals with visual impairment can make entertaining workouts without the problem of hinderance perception by taking the development of motor skills to the top level, such as balance, coordination, quickness and skills, after learning basic positions and applying them under complicated circumstances.

In short, the basic position training of individuals is very importantin terms of gainining proper body grip, forming the base structure of the positions that the learned skills include in athletic abilities, being used as the group exercise model, preventing the loss of time in learning the sporty skills, applicability on each level depending on the physical competence, forming the basis of the warming and weight workouts, the applicability in all spaces, the ability to be applied in the current position without a need to change it, and being a necessity for each branch of sport (Suveren, 2002).

\section{B. Basic Posture}

\section{1). Basic Foot Postures When Standing}

These are the postures made with different body positions on two feet (Suveren, 2002; Sezen \& Hazar, 2008; Yaçın, 1995). Standing postures come to the fore especially in correcting postural related disorders. They are effective in spatial perception and the development of kinesthetic sensitivity. It is advised to start to the teaching of basic postures with the help of a wall. In the next stage, the movements should be repeated far away from the wall and the practices should be improved by correcting the errors. In the improvement stage, the movements can be applied by changing their angles, increasing the width, and adding right, left, forward and back rotations or in the form of consecutive order (Suveren, 2002).

\section{2). Basic Postures Utilizing Hands and Feet}

These are the postures made by standing on both feet and hands with the support of different body positions (Suveren, 2002; Sezen \& Hazar, 2008; Yalçın, 1995). The strengthening of the arms, back and body muscles is important in terms of perceiving the body in different directions and forms. While standing close to the ground in 
quadruple form facilitates the control of the body, it also includes a very rich range of variants in terms of required strength exercises, enabling game-specific exercises and performing different exercises (Suveren, 2002)

\section{3). Basic Postures and Sets of which Standing Surface is the place where the Hip and Legs stand}

These are the sets and postures made with different body positions on the hip (Suveren, 2002; Sezen \& Hazar, 2008; Yaçın, 1995). They are especially used in warming, flexibility and in cascading of some gymnastic elements.

\section{4). The Basic Postures of which the Standing Surface are the Whole Body}

These are basic postures in which all parts of the body are in contact with the ground (Suveren, 2002; Sezen \& Hazar, 2008; Yaçın, 1995). These are especially important in terms of improving the sensation of torso muscles, strenghtening of these muscles and in the exercises protecting the integrity of the connection of body parts for the visually impaired people (Suveren, 2002).

\section{5). Basic Postures in which the Body Weight is carried by the Arms}

These are the basic postures in which the whole body is carried on up of the hands or with the hands (Suveren, 2002).

\section{Teaching and Practicing Stages of Basic Postures}

The curricula to be prepared for the basic postures should be specifically prepared according to the needs of disabled people, taking into account the disability situations and the levels of disability. Exercise content should be created in three steps: preparatory training, curative and developmental physical training exercises (Gallahue, 1987; Çalışkan et al., 2006).

\section{1) Preliminary Stage}

At this stage, which may vary according to the situation of the hinderance, the method of preparing the body for the visually impaired individuals can be used. The desired movement is explicitly and clearly explained so that the person can imagine it, thus it is ensured that the person has an idea of the movement and then $\mathrm{s} / \mathrm{he}$ is asked to apply the movement (Suveren, 2003; Suveren, 2002; Pogrund et al., 1998).

\section{2). Learning and Application Stage}

Teaching of the standing postures can be started in front of the wall, by leaning onto the wall or getting support from the wall with the hands for the purpose of cascading and adaptation (Pogrund et al., 1998). In this way, while the body maintains its balance more easily, the mind collects the data related to the concept of direction and the location of the body. At the same time, teaching the exercises with the help of a wall is also recommended for reducing the anxiety felt before starting the exercise (Suveren, 2003; Suveren, 2002; Pogrund et al., 1998).

In the cases which the head, the arm, and the legs are used inaccurately, these mistakes should be definitely corrected with the oral and physical help of the trainer (Pogrund et al., 1998). After all the errors in the movement have been corrected, keeping the individual in the desired posture for a certain period of time is very important in terms of the development of the muscular memory and the correct learning of the body position. In this way, learning becomes more permanent and effective (Suveren, 2003; Suveren, 2002; Pogrund et al., 1998).

\section{3). Proficiency (Perfecting) Stage}

At this stage, learned skills are applied without the use of assisting materials such as walls. Mistakes that occur during the practice are continuously corrected verbally and physically so that the applications of the movements are made accurately without mistake. The degree of difficulty of the applied skills should be increased by changing the angles of the basic positions made far from the wall according to their variety, increasing the widths of movement and taking the person's capacity and general situation into account. The person should reach the proficiency of doing the movement accurately when only the name of the basic position is said (Suveren, 2003; Suveren, 2002).

\section{Improving the Movements and Making Stages to More Difficult Applications (Complicated Conditions)}

Basic posture practices can be used as a basic building block to facilitate the learning of difficult movements. Repeating the movements a number of times in teaching methods and applying the simple movements under complicated conditions are very supportive in providing the movement improvement in visually impaired individuals. 


\section{Conditions;}

- Performing the simple movements in a successive order or movement combinations by connecting them with a different element (moving forward, then moving to the side by changing direction or vertical jump from squatty posture).

- Performing the simple movements by modifying the application surface (hard, soft, narrow or wide floor applications or material usage, etc.)

- Making simple movement exercises by attaching light weights to the body, arms, or legs

- Simple movements can be complicated using counter-force (paired working, leaning towards the wall etc.) or by applying at different speeds.

In visually impaired individuals, it is useful to complicate the conditions without changing the movements in terms of timesaving. Being familiar with the movements and the commands given by the instructor can be effective in shortening the perception and application period. The individual can use the time more effectively to develop a previously learned movement, as opposed to spending it to learn a new movement. Thus, the individual can make greater progress in terms of physical development in shorter time (Suveren, 2003; Suveren, 2002).

\section{Method}

15 visually impaired (B1 n:4, B2 n:6, B3 n:5) sedentary students who study at Special Education Department at the Faculty of Education in Gazi University and who attend to Physical Education and Game Teaching course have participated in our study. First of all, verbal information is given regarding the research and the students were asked to try 5 pre-determined movements. During the application, difficulties encountered by the students and the instructor, technical mistakes and the needs for the quality of movement were determined through observation by the international artistics gymnastics judge and the foundation of the study was established. Later, information was given related to the importance, grouping and application of the basic postures. During the following 10 weeks, studies have continued in the practice section of the course ( 1 day, 45 minutes per week) and all the basic postures included in the program with the instructor's verbal and physical help were applied. After 10 weeks, visually impaired students were asked to redo the 5 movements that were given in the beginning. During the study, performance of movements with the correct technique and body grip instead of many repetitions and long-time practice and the ability of visually impaired individuals to bring the verbal stimuli into practice were aimed. The study was conducted with method of compilation and the results were recorded based on the international judges observation.

1) Basic Foot Postures When Standing

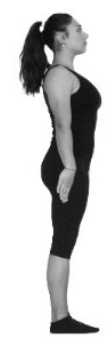

Picture 1. Basic posture

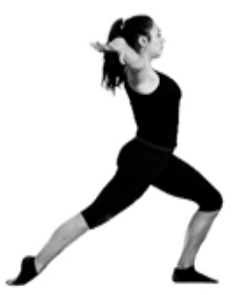

Picture 3. Forward movement

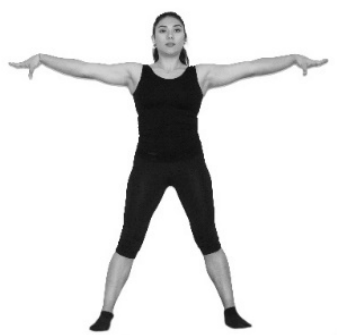

Picture 2. Basic open leg posture

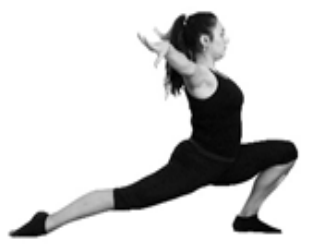

Picture 4. Wide forward movement 


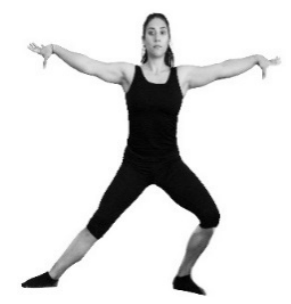

Picture 5. Side movement

2) Basic Postures Utilizing Hands and Feet

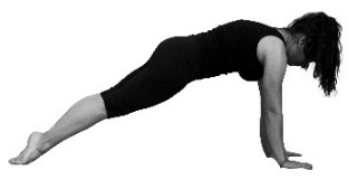

Picture 7. Bent front support posture

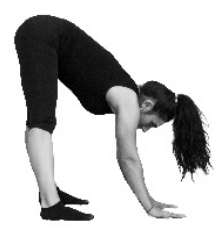

Picture 9. Bear posture

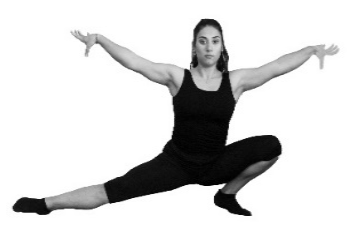

Picture 6. Wide side movement 
4) The Basic Postures of which the Standing Surface are the Whole Body

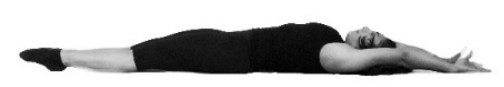

Picture 19. Lying on the back

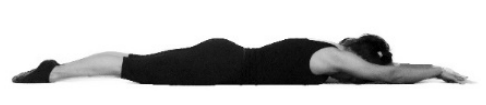

Picture 20. Face down lying

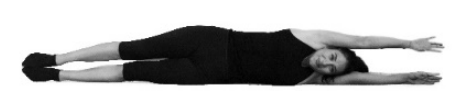

Picture 21. Side lying

5) Basic Posture in which the Body Weight is carried by the Arms

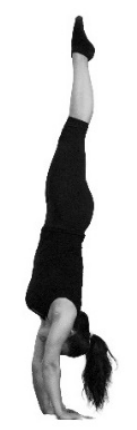

Picture 22. Handstand

\section{Selected Movements:}

1) Putting arms up from the front and/or side by lifting the heels from the floor, waiting 2 seconds and returning to the beginning position

2) A small jump by pushing against the floor with the feet from the hand-supported bear posture and coming to the bent front support position while keeping the hand support, then again a small jump and returning back to the bear position with hand support.

3) From the long sitting to the open leg sitting and returning to the long sitting (Without Hand Support)

4) From sitting on the hip, stretch out the legs forward without touching the floor and pulling back while getting hand support on the ground from the back.

5) From the face down lying position applied by getting support from the ground with hands and feet in a way that the balance beam is placed on the lower abdomen to the 8-10 seconds waiting position on the abdomen by lifting arms and legs (the arms and legs are in the space and the body is on the line)

\section{Discussion and Conclusions}

Progress in the development of motors skills of visually impaired individuals in a similar way with the sighted ones depends on the content of the education to be provided (Pogrund \& Fazzi, 2002)

Pogrund \& Healy et al. mentioned in their book about the activities that may be performed to develop attending behaviors as well as postures and walking of visually impaired students and highlighted the importance of teaching with auditory stimuli and performing activities with the help of wall (Pogrund et al., 1998).

In these studies, auditory input is crucial for reaching the target information. In expressions, attention should be paid to dimensional expressions such as direction, height, body position, and correct sequencing elements, and they should allow the individual to animate the movements in the mind. The mental preparation process allows the individual to be more effective in the application phase and more successful in acquiring mobility skills. Beside the explanations, the individual should get assistance for the tactile sensing of the movement. The instructor should actively participate in the movement (Y1lmaz, 2003; Suveren, 2003; Suveren, 2002).

It may be concluded from the parent resource manual prepared by Robinson \& Lieberman (2007) that they had conducted a study focusing on the effect of independent mobility skill on the physical activity levels of visually impaired individuals (Robinson \& Lieberman, 2007). The study conducted highlights the importance of the tips given physically or verbally and states that mobility activities may be performed with the help of wall.

These studies that do not require changing of the place are rich and in variety such that the individual do not have any problem in sensing the hinderance, can meet the need of movement, and can discover her boundaries. Applications can be made at each level (easy to difficult individually, paired, with group or additional tools (wall fence, resistance tire, small weights, rope, hoop, etc.) (Suveren, 2003; Suveren, 2002). 
Chen et al. studies results showed that 10 weeks of rope jumping exercise training could have a significant effect on improving the flexibility and aerobic capacity of visually impaired students (Chen \& Lin, 2011). In a similar study Shin et al studies claim that after the 6 weeks of indoor rowing using Concept 2 Model E., visually imparment subjects fat mass and total body fat percent decreased significantly and In the fitness test, back strength and trunk flexion score increased significantly (Shin et al., 2015).

Yilmaz et al. studies results showed that it has been determined that two months long basic judo training applied on visually impaired students has significant positive effects on physical developments of handicapped students (Yılmaz, 2003).

There are various training programs in the literature. In this study, basic posture exercises were used and the relationship between the positive effect of basic posture exercises on independent movement of visually impaired subjects and improved performance are parallel to the studies in the literature.

Prioritizing the teaching of basic postures in movement training and the training of sportive skills in visually impaired individuals is very important in terms of body awareness and spatial orientation. The results of the study has shown that the correct and technical learning of basic postures forms the basis of newly learned movements, allows time saving, and contributes to the strength and skill development, and helps to increase the variety of movements easily and quickly.

It can be said that basic posture exercises are the greatest facilitators of the instructors, if fuctionalisation of posture-related muscles are aimed especially in posture disorders (Suveren, 2003; Suveren, 2002).

In conclusion, it has been observed that the visualy impaired indiviuduals who have learned the basic postures successfully by getting verbal and physical support could apply the movements that include complicated conditions more easily and correct compared to the first trial, and their movement qualities (technical performance) have considerably increased. Therefore, it can be concluded that the basic postures are quite necessary for visually impaired individuals in terms of physical progression.

In accordance with these results;

For all disabled people at all levels, it can be recommended to carry out workouts that contain complicated conditions with additional tools, to observe the developments of visually disabled sedentary and athletic individuals, to organize informative seminars (as part of the in-service training programs) with instructors, to include movement transfer studies in training of sportive skills, and to increase the awareness by getting assistance from the abled students for the visually impaired students by applying the practices within the framework of inclusive education.

\section{References}

Altunay, B. (2003). Görme yetersizliği olan çocuklarda yönelim ve bağımsız hareket becerileri. In U. Tüfekçioğlu (Ed.), İsitme, konuşma ve görme sorunu olan çocukların eğitimi (ss. 275-300). Eskişehir: Anadolu Üniversitesi Yayınları.

Arslantekin, B. (2014). The Effects of Visual Impairment on Psychomotor Development and Independent Mobility and Supportive Programs. Ergoterapi ve Rehabilitasyon Dergisi, 2(3), 165-175.

Brambring, M. (2006). Divergent development of gross motor skills in children who are blind or sighted. Journal of Visual Impairment \& Blindness, 100, 620-634.

Çalışkan, E., Pehlivan, A., İnal, S., Dane, Ş., \& Akar, S. (2006). Goalball Sporunun Ve Hareket Eğitiminin Görme Engelli Çocukların Fiziksel Uygunluk Üzerine Etkilerinin Değerlendirilmesi. Journal of Physical Education and Sport Sciences, 8(3).

Chen, C. C., \& Lin, S. Y. (2011). The impact of rope jumping exercise on physical fitness of visually impaired students. Research in Developmental Disabilities, 32(1), 25-29. https://doi.org/10.1016/j.ridd.2010.08.010

Coughlan, G. F., Fullam, K., Delahunt, E., Gissane, C., \& Caulfield, B. M. (2012). A comparison between performance on selected directions of the star excursion balance test and the Y balance test. Journal of Athletic Training, 47(4), 366-371. https://doi.org/10.4085/1062-6050-47.4.03

Craft, D. H. (1995). Visually impairments and hearing losses. In J. P. Winnick (Ed.), Adapted Physical Education and Sport (pp. 143-166). Champaigne.

Deliceoğlu, G., Çavuş, T. P., Karaman, G., Kocahan, T., Tortu, E., \& Tekçe, A. (2017). Goalball Antrenmanının Kadın Goalball Paralimpik Takımının Kuvvet, Denge ve Esneklik Parametrelerine Etkisinin İncelenmesi. Gaziantep Üniversitesi Spor Bilimleri Dergisi, 2(1), 74-84. 
Gallahue, D. L. (1987). Developmental Physical Education for Today's Elementary School Children: Instructor's Resource Manual with Transparency Masters. Macmillan.

Havik, E. M., Steyvers, F. J. J. M., Van der Velde, H., Pinkster, J. C., \& Kooijman, A. C. (2010). Design and evaluation of a protocol to assess electronic travel aids for persons who are visually impaired. Journal of Visual Impairment \& Blindness, 84-94.

Horak, F. B. (1987). Clinical measurement of postural control in adults. Physical Therapy, 67(12), 1881-1885. https://doi.org/10.1093/ptj/67.12.1881

Kalia, A. A., Legge, G. E., Roy, R., \& Ogale, A. (2010). Assessment of indoor route finding technology for people who are visually impaired. Journal of Visual Impairment \& Blindness, 104(3), 135-147.

Montarzino, A., Robertson, B., Aspinall, P., Ambrecht, A., Findlay, C., Hine, J., \& Dhillon, B. (2007). The impact of mobility and public transport on the independence of visually impaired people. Visual Impairment Research, 9, 67-82. https://doi.org/10.1080/13882350701673266

Murphy, M. F. (1989). O'drriscoll M. Observations on the Motor Development of Visually Impaired Children. Physiotherapy, 75(99), 505-508. https://doi.org/10.1016/S0031-9406(10)62300-0

Pogrund, R. L., \& Fazzi, D. L. (2002). Early Focus: Workin with young children who are blind and visually impaired and their families (2nd ed.). New York: AFB Press.

Pogrund, R. L., Healy, G., Jones, K., Levack, N., Martin-Curry, S., Martinez, C., ... Vrba, A. (1998). TAPS: Teaching age-appropriate purposeful skills: An orientation and mobility curriculum for students with visual impairments (2nd ed.). Austin: Texas School for the Blind and Visually Impaired.

Robinson, B., \& Lieberman, L. J. (2007). Influence of a parent resource manual on the physical activity levels of children with visual impairments. RE: View, 39(3), 129-139. https://doi.org/10.3200/REVU.39.3.129-140

Sezen, M., \& Hazar, M. (2008). İlk ve Ortaöğretim Okulları Beden Eğitimive Spor Yüksek Okulları için Genel Cimnastik. Ankara.

Shin, K. Y., Choi, E. H., Lim, J. Y., Cho, A. R., \& Lim, Y. H. (2015). Effects of indoor rowing exercise on the body composition and the scoliosis of visually impaired people: a preliminary study. Annals of Rehabilitation Medicine, 39(4), 592-598. https://doi.org/10.5535/arm.2015.39.4.592

Suveren, S. (2002). Görme Engellilerde Serbest ve Aletle Cimnastik Uygulamaları,T.C. Görme Engelliler Spor Federasyıonu, Temel Eğitim Semineri, 28 ocak-1 Şubat, 2002 Manisa-Akhisar.

Suveren, S. (2003). Görme Engellilerde Serbest ve Aletle Cimnastik Çalışmaları G.Ü.B.E.S.Y.O., Beden Eğitimive Sporda Sosyal Alanlar Kongresi 10-11 Ekim 2003 Ankara.s.91-95.

Yalçın, H. F. (1995). Beden Eğitimi Öğretmeni El kitabı: G.Ü Yayın no.203, Gazi Eğitim Fakültesi Yayın no.24 .2.bask1. Ankara.

Yılmaz, S., Tatar, Y., Ateş, O., \& Tiryaki, E. (2013). Judo Sporunun Görme Engelli Oğrenciler Uzerine Etkisinin Bazi Parametreler Acisindan İncelenmesi. Spor Bilimleri Dergisi, 3.

\section{Copyrights}

Copyright for this article is retained by the author(s), with first publication rights granted to the journal.

This is an open-access article distributed under the terms and conditions of the Creative Commons Attribution license (http://creativecommons.org/licenses/by/4.0/). 